Newfoundland and Labrador Studies

\title{
The Newfoundland Tempest: Theatre of the Cultural Revival, the LSPU Hall, and Shakespeare
}

\section{Robert Ormsby and Michelle King}

Volume 35, Number 1-2, 2020

URI: https://id.erudit.org/iderudit/1076766ar

DOI: https://doi.org/10.7202/1076766ar

See table of contents

Publisher(s)

Faculty of Arts, Memorial University

\section{ISSN}

1719-1726 (print)

1715-1430 (digital)

Explore this journal

\section{Cite this article}

Ormsby, R. \& King, M. (2020). The Newfoundland Tempest: Theatre of the

Cultural Revival, the LSPU Hall, and Shakespeare. Newfoundland and Labrador

Studies, 35(1-2), 7-50. https://doi.org/10.7202/1076766ar viewed online.

https://apropos.erudit.org/en/users/policy-on-use/ 


\section{The Newfoundland Tempest. \\ Theatre of the Cultural Revival, the LSPU Hall, and Shakespeare}

Robert Ormsby and Michelle King

\section{Introduction}

The Newfoundland Tempest, staged in 1982 at the LSPU Hall and the Arts and Culture Centre (ACC) in St. John's, appeared at an important juncture in Newfoundland and Labrador's cultural history. ${ }^{1}$ The year marked the beginning of annual Shakespeare performances on the island by local theatre artists after more than a century of infrequent professional touring productions from abroad and amateur companies' occasional stagings of the playwright's work. The production was mounted by the Resource Centre for the Arts (RCA) at the end of the first phase of the "Newfoundland Renaissance" and embodies key aspects of this cultural revival, including the province's ambivalent relationship to its British heritage, the development of Newfoundland identity as expressed in beliefs about political self-determination within Canada, and artistic nativism. ${ }^{2}$ Because of the ways this Tempest combined these features of the revival, the production can be seen in light of late twentieth-century appropriations of the play that asserted the right of those on the margins of empire to cultivate a sense of local identity by taking control of the drama's narrative. ${ }^{3}$ As Ania Loomba argues, numerous writers and thinkers influenced by twentieth-century decolonization movements framed The Tempest "as a parable of colonial relations," with Prospero as an invader and Caliban as his colonized subject (161). For anti-colonial adapters, it became "a powerful cultural 
symbol to be seized and used for their own ends" (Loomba 164). The best-known such adaptation is Une tempête by Martinique writer Aimé Césaire, who "believed that it was crucial for the colonized Martinician people to relocate themselves at the centre of the stage" (Rix 236). His adaptation was meant to claim ownership of the play or, in Lucy Rix's words, "to 'protagonize' the colonized and to ensure that their voices were heard loud and clear" (236). The RCA's Tempest "protagonized" contemporary European-descended Newfoundlanders, not by depicting them as Calibans but, like other theatre of the cultural revival did, by looking to Newfoundland's European artistic inheritance, and drawing on the island's past to gauge the present and suggest a direction for the island's future (Overton, "Towards" 232; Gulliver 22). Yet, whereas artists of the cultural revival were inspired by rural Newfoundlanders' domestication of traditional European folk performance, the 1982 Tempest drew on the metropolitan high-culture author of British literary heritage in novel ways.

While the RCA's Tempest put Newfoundland "at the centre of the stage" insofar as it was set on the island in the 1750s and depicted the play's villains as merchants and Caliban as a Beothuk, the production was conceived of and directed by Toronto-based theatre artist Steven Bush. He had worked previously with the innovative and politically engaged Toronto Workshop Productions, a company committed to "collaborative/collective" theatrical creation (Bush, "George" 162). Bush also acted with and directed for The Mummers Troupe in 1975, and he recounts that, having spent time in Newfoundland, he proposed the idea of setting The Tempest there to the RCA (Bush, "Remembering" 68). ${ }^{4}$ Although Bush worked in Toronto, most of the cast were local performers, including key figures of Newfoundland's cultural revival: besides Andy Jones (as Prospero), who was a member of local theatre collectives CODCO and Sheila's Brush, the production relied heavily on the live music of Figgy Duff, who reworked traditional Newfoundland folksongs with electric guitars and keyboards. ${ }^{5}$ At the same time, the production signalled its respect for Shakespeare's literary reputation by playing his script virtually uncut, and, by making 
a central tenet of the production the idea that English spoken in Newfoundland is authentically Shakespearean, Bush and the RCA combined the island's imagined mid-1700s history with the playwright's literary prestige (Bush, "Proposal" 1,3). The 1982 Tempest thus used a purportedly shared linguistic past to make claims on England's national poet in advancing beliefs about Newfoundland identity.

The RCA Tempest was significant for the way it construed Newfoundland's relationship to Shakespeare, but it also reflected important changes to the theatre that were underway in the province in the early 1980s. These changes are related to the evolution of the professional theatre of the cultural revival; as Denyse Lynde wrote of theatre in St. John's in 1989, "the collective creation of the 1970s and early 1980s is being re-examined, re-evaluated, and in some ways left behind" because the "community has developed a broader focus encompassing direction, design, and play text" (691). This evolution included a new organizational structure for theatre production, the rationalized availability of the LSPU Hall for artists, and improved relationships with governmental organizations (Gulliver 272-74, 282). In the case of The Tempest, the production was not created by a collective, which is a relatively democratic production arrangement closely associated with the two best-known theatre companies of the Newfoundland Renaissance, The Mummers Troupe and CODCO. Rather, it followed a hierarchically structured production process in which a single director assumes responsibility for conceiving and executing an approach to a lone playwright's scripted drama that is acted by a professional cast, each member of which is paid by the producing company. ${ }^{6}$ The show ran during a period of relative stabilization for this newly professionalized community of artists in a performance space governed by a board for the benefit of a local urban constituency and the province as a whole. Transferring the show to the provincial Arts and Culture Centre system, with four ACCs on the island outside St. John's, for a proposed (though finally cancelled) tour of the island embodied this sense of responsibility, but it also represented a momentary easing of tensions with the large governmental arts institution often accused of marginalizing Newfoundland culture (Gulliver 55-62). 
While scholars have extensively covered the cultural revival of the 1960s and 1970s, less has been written about how the issues outlined above affected the next phase of theatre in Newfoundland, and relatively little has been written on either Shakespeare in the province or on the RCA. ${ }^{7}$ We will consider The Nerufoundland Tempest as a Shakespearean performance and as a production that sheds light on how Newfoundland theatre, particularly that in St. John's, was then evolving. The production may not have initiated a major shift in the nature of that theatre, but detailing the show's contexts of creation and reception reveals two things: that it was part of a transformation of the broader forces and ideals that shaped the cultural revival in the early 1980s; and that the RCA's Tempest provided a model for domesticating Shakespeare as part of Newfoundland's heritage, a model that anticipated later developments in Shakespearean theatre by Newfoundland and Labrador practitioners.

\section{Theatre of the Cultural Revival and the LSPU Hall}

The development of theatre in Newfoundland during the 1970s and the transfer of ownership of the LSPU Hall to the RCA are logical outcomes of the processes at work in the cultural revival. Scholarship about the revival of the 1960s and 1970s depicts a rapidly changing society reworking the past for contemporary purposes by channelling its history into artistic forms and institutions that were not, strictly speaking, part of the local rural tradition from which they drew inspiration. This artistic, educational, and broadly social movement concerned with preserving the province's culture arose in response to the perception that forces of modernization, industrialization, urbanization, and homogenizing North American mass media threatened Newfoundland's unique heritage. The movement's exponents criticized the post-Confederation policies of Joseph Smallwood's Liberal government, especially the resettlement of outport communities, thereby linking culture and economics (Overton, "Towards" 226) as part of a more general rejection of modernity and a quest for cultural 
authenticity (Gulliver 16, 24; Overton, "A Newfoundland" 8). The movement was for some a response to the blow to their identities that Newfoundlanders ostensibly experienced in the decades after losing responsible government during the Commission of Government and joining Canada as its tenth province.

Yet, a central contradiction of the cultural revival is that, as in earlier eras, claims about Newfoundland's unique ethos were made during the 1960s and 1970s in terms defined by those outside the province: artists of the revival were influenced in their understanding of rural life, anti-materialism, and political performance by movements formed in North America and Europe. ${ }^{8}$ Moreover, the image of the traditional rural folk under threat was developed in contrast to the perceived rootlessness of modern cosmopolitanism by urban intellectuals and artists who were themselves the product of the modernity they criticized (Gulliver 18). In identifying and selecting which customs were authentic, these thinkers and artists repurposed traditions originating in quotidian rural existence, rendering them as "collective identity systems for a [Newfoundland] culture" (Pocius 59). ${ }^{9}$ The artists who participated in this process reframed tradition through visual arts, theatrical and musical performance, and festivals that were, according to James Overton, meant "for consumption by the new middle class" ("A Newfoundland" 8), and thereby helped create "new institutions catering to the arts" for educated urban audiences (Overton, "Towards" 223). ${ }^{10}$ As we will argue, both these institutions and the urban audiences they served were deeply affected by post-war Newfoundland's modernizing reforms; the rise of Newfoundland's theatre institutions in the 1970s was shaped by such reforms, by intellectual currents and media originating outside rural Newfoundland, and by the influence of major Canadian cultural agencies.

Aspiring professional Newfoundland theatre artists in the early 1970s had to develop their own institutions because they received little support from provincial agencies. There was hardly any "formal [governmental] expression of arts policy until the Division of Cultural Affairs was established in 1971" (Rompkey 271); prior to 1980 no official 
provincial arts council or other arm's-length agency existed to deliver regular funding to theatre groups; and, before the 1970s, the only professional venue for Newfoundland actors and playwrights was the Canadian Broadcasting Corporation (CBC; Ferry 145). The other main venues, the provincial ACCs, were regarded by some as symbolic of all that was wrong with the province's artistic establishment. One influential, if tendentious, narrative is that the ACCs' "tuxedos and ball gowns" elitism (Gulliver 60) combined a reflexive colonial deference to British culture, wilful ignorance of original Newfoundland theatre, and a commercial imperative that led ACC management to book artistically bankrupt but popular entertainment from outside the province for tours of its large auditoriums. ${ }^{11}$ Local performers who could not fill those large spaces lacked appropriate venues for their shows, and Mummers Troupe co-founder Chris Brookes even claimed that the ACCs' first director, John Perlin (also the first Director of Cultural Affairs), marginalized Newfoundland theatre by relegating it to the St. John's Centre's small Basement Theatre (Gulliver 60).

The one provincial organization that theatre artists could look to for conceptual models, infrastructural support, and training was Memorial University, which played a key role in the institutionalized reframing of tradition by laying much of the groundwork for the cultural revival. As Jeff Webb has demonstrated, founders of the Newfoundland Studies movement at the university employed modern concepts and methodologies originating in North America and Europe to develop their idea of Newfoundland society as essentially rural, one that could be recorded, analyzed, and celebrated in then-current modes of academic knowledge (Observing 4-24). These academics disseminated that knowledge in publications and in classrooms to thousands of students to preserve in scholarship and pedagogy the traditional ways of life that they believed were threatened by the modernity they were themselves promulgating (Webb, Observing 4,24). Memorial's Extension Service was also crucial to the revival; in St. John's it provided infrastructure, including off-campus rehearsal and performance space (Webb, "The Rise" 98). Such provisions, along with workshops, classes, 
an artist-in-residence program, and assistance writing grant applications, meant that artists could develop their work in the province, rather than having to move away to do so (Gulliver 147). Memorial's Extension Service thus played an important part in encouraging a generation of practitioners who had equipped themselves to observe, analyze, and celebrate Newfoundland culture in modern media, including contemporary forms of theatre.

Support from federal agencies, too, significantly influenced the development of Newfoundland's professional theatre community. Most scholarship about that development focuses on CODCO and The Mummers Troupe, which created professional theatre as collectives using Newfoundland material that they combined with non-traditional modes of performance. A third group, The Newfoundland Traveling Theatre Company (NTTC), has received far less critical attention than the other two companies. ${ }^{12}$ The contrasting fortunes of CODCO and The Mummers reveal that the evolution of the cultural revival is connected to the companies' relationships with national cultural institutions and that support from these federal institutions had unintended consequences for the province's theatre artists whose practices were not common to the traditional culture they celebrated.

While writing on CODCO has treated the collective as the sharply comic and commercially viable theatrical face of the cultural revival, the company was influenced by culture from outside Newfoundland and CODCO's success was fostered by mainland Canadian institutions. With an incisive political satire that attacked social and economic inequalities and artistic elitism, CODCO showed audiences in the province "that comedy could be made from the fabric of their everyday lives" (Peters, "Introduction," The Plays xiii). At the same time, the company dealt with political issues central to the cultural revival, such as the relationship between urban elites and rural communities (Peters, "Introduction," The Plays xxvi). While the episodic structure of many CODCO plays may have shared approaches to performance with traditional Newfoundland concerts (Skinner 89), their productions reworked Newfoundland subject matter under the influence of British and North 
American sketch comedy and television (Gulliver 244). The company was also influenced by the Canadian alternative theatre scene. CODCO members' experience of working in that milieu sharpened their sense that Newfoundlanders were outsiders within Canada, inspiring them to write about those experiences in their first production, Cod on a Stick, which was funded and staged by Toronto's Theatre Passe Muraille (Peters, "Introduction," The Plays xi-xii; Gulliver 244). Significantly, CODCO was instrumental in turning the cultural revival outward: making "a conscious effort to change mainland Canadian thinking about Newfoundland" (Peters, "Introduction," The Plays xxviii), they cultivated audiences beyond the province in the 1970s. The company's success on CBC television in the 1980s and 1990s extended the reach of the cultural revival by channelling its theatrical material through a mass medium and the country's largest publicly funded cultural institution. Thus, ironically, CODCO used the institutionalized technology of modernity, which artists of the revival denounced, to give Newfoundland a prominent voice within the mainstream of a national culture, the influence of which supposedly threatened Newfoundland identity.

The Mummers, by contrast, has been depicted as embodying the contractions and restrictions that the revival's politically committed theatre was susceptible to. In criticizing revivalists in St. John's for ignoring then-contemporary rural people's cultural preferences, Gerald Pocius singles out The Mummers for venerating the Mummers Play, versions of which they performed repeatedly over Christmas seasons up to 1981. He comments that the company "hoped to resurrect what they considered a pure form of indigenous culture that was, in fact, never very widespread in Newfoundland" (63), and claims that the particular play they performed was likely a dramatic genre imposed by a ruling class in Britain to contain within scripted behaviour the anarchic improvisation of working-class mummers during visits to the gentry's homes. The Mummers, he asserts, "chose to revive a cultural form"-scripted drama, not unstructured house visits that had been common in Newfoundland-"that was ultimately a product of the very genteel class that they felt had ignored Newfoundland culture" (62-63). Pocius's remarks are 
contentious and he acknowledges they do not apply to all of the long and varied history of mummering in Newfoundland. To the extent that he is correct about the specific version of the Mummers' play the company chose to perform, though, such comments highlight the irony of urban artists mistaking the "genteel" dramatic convention for the rural Newfoundland tradition of mumming. ${ }^{13}$ Still, Pocius focuses on questions of authenticity and does not take into account the considerable amount of urgently topical and politically engaged work The Mummers did with rural communities (Brookes, A Public 78-96, 111-27). Of course, that work was influenced by experimental, collectivist theatrical practices and political ideologies originating outside Newfoundland (Filewod, "The Mummers" 6, 10; Gulliver 218, 243; Peters, "Introduction," Stars xxi), many of the actors who performed with the company were from mainland Canada (Brookes, A Public xii-xiii; Filewod, "The Mummers" 6), and much of The Mummers' work was funded by agencies outside Newfoundland. ${ }^{14}$

The containment Pocius identifies was less consequential than the one The Mummers experienced when they failed to meet the expectations of the Canada Council and ceded control of the LSPU Hall. Alan Filewod's penetrating analysis of the company demonstrates that the collective succumbed while trying to "shift from crisis to rationalized management" ("The Mummers" 4). Their acquisition of federal funding allowed them to purchase the building in downtown St. John's as a permanent theatre space, and both funding and the venue brought with them "increased responsibility" and bureaucratic scrutiny (Filewod, "The Mummers" 15, 19). In addition to repeated calls from the collective's members to clarify ownership of the company and relationships of authority within it, The Mummers Troupe was subjected to demands that they conform to the strictures of the Canada Council (Filewod, "The Mummers" 25-28). When the company failed to do so, the central Canadian bureaucracy rationalized a reduction of their funding, which helped sideline them, precisely the kind of governmental marginalization that fuelled anger underlying the cultural revival (Filewod, "The Mummers" 25-31). 
The marginalization and decline of The Mummers, which included transferring ownership of the LSPU Hall in 1979 to the RCA, could be seen as a turning point in the history of both Newfoundland theatre and the cultural revival as local artists' interests aligned with the bureaucratic constraints of the Canada Council. ${ }^{15}$ In March of 1979 , the St. John's artistic community organized itself to seek greater access to the building by opening up membership to the public in the Resource Foundation for the Arts (RFA), which operated the LSPU Hall, and by separating The Mummers from the RFA (Open Letter). As tensions grew and The Mummers and the LSPU Hall were threatened with a boycott by community artists, a committee was struck to resolve the dispute. ${ }^{16}$ The committee's report satisfied the kind of organizational clarity the Canada Council had required of The Mummers, dividing resources according to the funding agency's logic. ${ }^{17}$ Their decisions, which democratized access to a crucial piece of the province's theatrical infrastructure, carried out the will of local artists by effectively enforcing the Canada Council's rationalizing approach to that infrastructure. That approach was subsequently enshrined in the highly structured organization described in the constitution drafted in November for the newly formed RCA that took over the LSPU Hall (Draft Revision). The institution that would be so important for Newfoundland theatre for decades to come, as a performance space and as a producing company, was thus reformed in the image of a cultural agency from outside the province. ${ }^{18}$

The categorical terms Brookes uses to portray the turning point of the LSPU Hall's new ownership gloss over the complexity of Newfoundland's theatre history from the 1960s to the early 1980s. For him, the RCA takeover occurred at a time when the province's theatre community had lost interest in rural Newfoundland, claiming that companies had stopped touring to small communities, that the province's actors and directors were mainly interested in "foreign plays" by "Joe Orton, Arthur Miller, Shakespeare" and that they had retreated to urban centres to perform for "exclusively urban middle-class" audiences (A Public 223, 222). This assessment overlooks both The Mummers' 
touring to communities outside St. John's after the RCA began managing the LSPU Hall ${ }^{19}$ and the rise of Sheila's Brush, a collective founded in the late 1970s "to write shows using music, theatre and dance based on the folklore and oral traditions of Newfoundland" ("A Short"), traditions they adapted to dramatize contemporary social issues. ${ }^{20}$ Similarly, RCA-produced tours, mostly of Newfoundland material, reached more than 12,000 theatregoers in the same period (RCA, Attendance). ${ }^{21}$ Furthermore, by establishing the LSPU Hall as a permanent performance space, Brookes and the RFA helped extend the local tradition in St. John's of staging an eclectic repertoire of plays by foreign and Newfoundland writers for urban audiences. ${ }^{22}$ RFA publicity portrayed the building as an affordable and "flexible" alternative to the ACC that would attract "local Newfoundland artists and groups" (A Proposal 2). By 1978, the RFA could boast that 27,000 people used the space in its first year, that it hosted theatrical performances, rehearsals, art exhibits, and meetings, and that the venue had made "an important cultural contribution to the quality of life in the city" (Quick-Reference 1). ${ }^{23}$ Between 1977 and 1979, the LSPU Hall, under RFA management, housed performances by theatre companies and musicians from Newfoundland and across Canada. ${ }^{24}$ From December 1979 to the 1982 season, when The Nerwfoundland Tempest appeared, the RCA continued the RFA's varied programming at the Hall, producing and co-producing 84 theatre shows, concerts, dances, and film series for over 30,000 people (RCA, Attendance). ${ }^{25}$

Both RFA and RCA programming at the LSPU Hall in fact mirrored contemporary offerings in the local arts community more broadly. Between 1977 and 1982, work by folk and classical musicians, children's performers, dance studios, school groups, puppeteers, and filmmakers from Newfoundland, mainland Canada, and overseas appeared regularly at venues throughout the city. ${ }^{26}$ Meanwhile, Newfoundland performers began moving between the LSPU Hall and the ACCs. ${ }^{27}$ These circumstances indicate that the RCA had not merely developed their space into a Newfoundland artistic institution structured and operated according to the bureaucratic rationale of a mainland Canadian funding 
agency. The artistic community had turned the venue into an outlet for their creative impulses, and the eclectic repertoire, which celebrated reclaimed traditional Newfoundland performance alongside international theatre, music, and film, is a clear manifestation of the external influences that shaped the cultural revival and Newfoundland culture more generally. The RCA's decision to produce its version of The Tempest in 1982 as a way of reclaiming Shakespeare as a Newfoundland tradition is thus consistent with what the company, the LSPU Hall, and the province's arts community had then become, even if the show helped move Shakespearean theatre in the province in a new direction. ${ }^{28}$

\section{Shakespeare in Newfoundland and The Newfoundland Tempest}

The Newfoundland Tempest was not, however, an inevitable production. As Peter Ayers demonstrates in his foundational essay on the subject, Shakespeare had a low theatrical profile in Newfoundland before the late twentieth century, though there is evidence of Newfoundlanders venerating the playwright as the embodiment of British values ("Learning" 192-94). ${ }^{29}$ Scholars have examined connections between the conventional prestige associated with performing Shakespeare and attitudes of certain Newfoundlanders' deference to British culture. Marlis Schweitzer persuasively argues that child prodigy Jean Davenport's 1841 performances of Richard III in St. John's and Harbour Grace should be understood in terms of British colonials' beliefs about masculinity, civility, and "Newfoundland's position within the imperial hierarchy” (62). Michelle King and Robert Ormsby relate how English actress-manager Florence Glossop-Harris used her Shakespearean roles to confer status on herself and her company when they toured to St. John's in 1926, 1928, 1929, and 1930 and reminded audiences that Shakespeare represented an important link between members of the British Empire (40-41). Separately, Pocius and Ayers point out how Brookes bluntly rejected the same connections between Shakespeare and colonial loyalties to assert that Newfoundland should instead look to its own histories and traditions (Pocius 62; Ayers, "Learning" 198). 
Yet, such examples are scarce and the attitudes they represent did little to change Shakespeare's marginal status in Newfoundland theatre before the early 1980s (Ayers, "Learning" 192-96). Davenport's 1841 Shakespearean performances, the first known ones on the island, were followed by a small number of nineteenth-century productions in St. John's and a tour to the city in 1900 by the Lyceum Company, which staged The Merchant of Venice, Hamlet, Othello, and Romeo and Juliet (King 137). Only 12 of the 66 plays that the Glossop-Harris Company staged during its tours to St. John's were by Shakespeare (King and Ormsby 38-39). In the seven years (1951-57) that they performed in the province, the London Theatre Company staged just two of the playwright's dramas, The Taming of the Shrew (1952) and The Merchant of Venice (1953) (Yeo). Memorial's Extension Service opened the University's Little Theatre in 1961 with a production of Macbeth, but the play choice was a concession to Catholic church authorities who objected to the original selection - Jean Anouilh's The Lark - and because Macbeth was on the school curriculum (Webb, "We can hardly" 81-82). Ayers plausibly attributes the scarcity of Shakespeare productions to the fact that his plays require large casts but cannot guarantee profitable ticket sales and to the tastes of amateur companies and their audiences, who preferred "West End or Broadway" theatre ("Learning" 194-95). Perlin echoes these sentiments when relating that the ACC could stage four Shakespeare plays between 1970 and 1974 only because the amateur cast worked for free and because the plays they chose were required reading for the province's students (58). The situation began to change, however, in 1978 when Bay Theatre staged Othello in Stephenville; shortly thereafter, Shakespeare's work appeared more regularly in the province (King 138).

The RCA's first Shakespeare-related performance at the LSPU Hall was A Midsummer's Nightmare, co-produced in July of 1980 with Sheila's Brush, and while records for the show are incomplete, they suggest the ways that Shakespeare could be accommodated to the aims of the cultural revival. ${ }^{30}$ The company's typewritten history describes the play as taking place "on an island off the coast of Nfld." where "a 
group of modern day revolutionaries" meets "the ghosts of those who fought against resettlement and confederation” (“A Short”). Such political action mirrors that of the modern revivalists by connecting the present to the earlier fight against cultural losses from urbanization and incorporation into Canada and by imagining a remote and haunted locale to be the staging ground for the revolution and tradition being dramatized in the theatre. No script for $A$ Midsummer's Nightmare is known to survive, but, as Terry Goldie's review (the only lengthy one of the production) relates, the play depicts the United States seizing Newfoundland's oil and transporting all but 25,000 citizens to Arizona where the province has been recreated as a "Disney replica" in the desert (Review). Newfoundlanders are thus displaced to an Americanized tourist version of their real homes, the opposite of the culturally authentic island where the revolution is born. Shakespeare, however, seems not to have been central to the action. The company history describes his comedy as an "outline" for the story of revolution ("A Short"), while Goldie indicates that the revolutionaries pretended to be actors rehearsing $A$ Midsummer Night's Dream. Shakespeare thus serves as "a cover" (Goldie, Review) for combatting American economic and cultural exploitation, but Sheila's Brush also satirically reworked Shakespeare, changing Hermia and Helena to "Hernia" and "Hyena" and Pyramus and Thisbe to "Pyrex" and "Frisbee," respectively (Goldie, Review). From Goldie's perspective, the actors did not replicate the respectful approach to high culture taken at Canada's main Shakespearean theatre venue: "the king's crown made from a Blackhorse [beer] box and the majestic codpieces on the men suggest that [the] Stratford [Festival in Ontario] is still far away" (Review).

The Newfoundland Tempest, too, reflected the aims of the cultural revival, but in ways respectful of Shakespeare's work and that showed a concern for the legacy of European colonialism in Newfoundland. In his 1980 proposal for the production, Bush depicts Prospero's relationship with Ariel as representing the conflict between the former's quasiscientific knowledge and the more traditional magic and culture of the latter, whom he imagines as, possibly, "an expatriate Druid" from 
Britain (4). Bush perceives a related conflict between the feudalism of the honest counsellor Gonzalo's speeches and the behaviour of the "three men of sin," as Ariel calls them: Antonio, who usurped his brother Prospero as Duke of Milan; Alonso, the King of Naples and Antonio's one-time ally; and Sebastian, brother to Alonso whom he and Antonio plot to kill. Bush portrays the three Machiavellian politicians as protocapitalist "individualistic power mongers" and associates them with "merchants from the West Country" or "St. John's" ("Proposal" 5). Besides mapping onto the play the critiques of materialism, technology, and rural-urban relations typical of the cultural revival, he regards the Europeans' scientific knowledge and economic system as key to their colonial project, embodied in Caliban, whom Bush portrays as a Beothuk dispossessed of land and "authority" ("Proposal" 4). ${ }^{31}$

While Bush uses the proposal to link cultural loss to economic exploitation in ways familiar from the cultural revival, he does not treat Shakespeare merely as a "cover" for contemporary Newfoundland politics. Rather, he asserts that Newfoundland is the ideal place to stage The Tempest: he suggests an indirect connection between John Guy's 1610 voyage to the Avalon Peninsula and Shakespeare's 1611 drama, remarking that, being "men of the same Age, of the same England," explorer and playwright shared understandings about "culture shock" ("Proposal" 2); he also notes that Newfoundland long sustained early modern performance traditions and beliefs in magic ("Proposal" 1). Significantly, he posits that Newfoundland speech preserves elements of "Elizabethan English"' ("Proposal" 1), and argues that the production is "an ideal opportunity for Newfoundland actors to research and further develop the rich variety of indigenous dialects" ("Proposal" 3). In this light, Shakespeare is not a foreign influence to resist but another tradition for Newfoundlanders to reclaim. Moreover, the benefits are mutual: "For audiences it should be a great pleasure to hear a Shakespeare text sounded so that not only is the music of the language redeemed but the words actually make sense" ("Proposal" 3). The production would thus, in Rix's phrasing, "protagonize" Newfoundlanders and, in "relocat[ing] themselves at the centre of the 
stage," would show how their linguistic exceptionalism can return The Tempest to a state of aural and semantic authenticity. This sentiment is analogous to the ideas that Memorial University researchers' were coming to terms with about Newfoundland English; recognizing that fact, the production team invited Professor Harold Paddock to rehearsals to discuss similarities between early modern and Newfoundland English (Bush, "Remembering" 70). Bush thus attempted to bring Shakespeare within the ambit of the revival by using local speech to recover the true meaning of the playwright's work as a cultural form that predates modernity, one that has a special relationship to Newfoundlanders. The effort is not simply to use Shakespeare to critique colonialism, but for Newfoundlanders to recognize a kinship with Shakespeare and to claim his work as their own.

Publicity echoed Bush's sentiments, though aspects of that publicity reflected a wariness about the reception overtly political Shakespeare would get in Newfoundland. The show's advertisements and poster feature a striking black-and-white photograph of Andy Jones dressed in Prospero's robe and clutching his magician's staff. It shows him on a rocky beach facing the Atlantic and a distant cliff with his arms stretched skywards, appearing to control the elements. Local spectators would likely have recognized the setting; the title, featuring a handwritten "Newfoundland" scrawled above the space between "The" and "Tempest," seems to clarify, rather, the image's Shakespearean connection. RCA program notes offer a digest of Bush's proposal to make the case for setting The Tempest on the island in the eighteenth century. However, no press release mentions issues of class or colonialism that the play might evoke or that Bush proposed. Instead, they refer to the play as "SHAKESPEARE'S BEST-LOVED ENTERTAINMENT" (RCA, Public Service Announcement) "with an added spirited jig and a reel” (ACC, Press Release). A publicity memo emphasizes this production will not be "stuffy," but "Shakespeare made interesting" with "magic and music," "fine clowns," and "lots of drunken rowdiness" (RCA, Publicity Checklist). This view of the production as entertaining rather than "stuffy" was widely distributed: numerous 
previews stressed the show's lighthearted fun and its Newfoundland features; many of them simply reprinted parts of the RCA's Public Service Announcement. ${ }^{32}$ Publicity typically appeals to audiences' taste for entertainment, but whoever was responsible for the announcement was evidently concerned about theatre-goers' aversion to challenging, high-culture Shakespeare. Furthermore, the memo's repeated publication widely circulated the association of Newfoundland Shakespeare with clowning and drunkenness, thereby trivializing the production's politics, especially Bush's proposed examination of the play's class relations and his concern to link Caliban's treatment with the dispossession of the Beothuk.

The production itself largely maintained Shakespeare's text while making the play easily recognizable to local theatre-goers as a product of Newfoundland culture. The archived sound recording indicates that Bush deleted only 50 lines (of approximately 2,300), resulting in a two-and-a-half-hour performance. The set located the action in what could be taken as a minimalist version of Newfoundland's landscape. On one side of the stage "scrawny spruce trees spangled with Christmas lights ... conceal[ed] Figgy Duff"; on the other was a "papier-mâché rock"; in between was "a split-log bridge" representing the ship (Conlogue). Archival photographs show actors in plausibly eighteenthcentury clothing that sorted most characters according to class. ${ }^{33}$ Kay Anonsen's Miranda wore a white satin gown, indicating her aristocratic status. Similarly, the high-status "three men of sin" - Kent Barrett's Antonio, Ed Kielly's Alonso, and Charles Tomlinson's Sebastian wore white frilled shirts under richly ornamented coats. Their servants' modest clothes clearly signalled their class: Anonsen's jester, Trinculo, wore striped half-trousers and knee-length stockings, while Michael Wade's Stephano had a white shirt under a plain brown jacket. Leon Sobieski's Caliban, with a mass of dark hair, was dressed simply in a grey sheet; he was evidently not one of the Europeans. Jones's costume did not link his Prospero only to the 1750s; he wore a brick-red cloak over a black hooded robe and carried a driftwood staff, suggesting he was a sage who could have been from almost any era. 
Certain performers delivered Shakespeare's verse in accents that audiences would have recognized as their own. As the archival sound recording indicates, Sobieski adopted several characteristic features of Newfoundland pronunciation when doubling as Gonzalo: he lengthened long "a" and long "o" sounds (e.g. "patience" to "pa-a-atience," 3.3.3; and "woe" to "wo-o-oe," 2.1.3); pronounced long "i" sounds as "oi" ("wife" as “woife," 2.1.4) and vice versa (e.g., "foison" as "fisin," 2.1.161); switched short "e" sounds to short "i" sounds (e.g., "weapons" to "wipons," 2.1.320); spoke short "u" sounds as a somewhat lip-rounded "o"-like sound (e.g., "lungs" as "looungs," 2.1.173), and spoke "oo" as "yoo" ("dukedom" as "dyookdom," 5.1.211). ${ }^{34}$ Such pronunciation associated Gonzalo, who regards this eighteenth-century Newfoundland as a utopia, with Prospero, Miranda, and Ariel, who have learned to live on the island: Jones's vocalization displayed all the features that Sobieski affected; Anonsen adopted them, too, for Miranda's lines, while also dropping some "h" sounds (e.g., "her" becomes "er," 1.2.13) and changing some "th" sounds to "d" sounds (e.g., "father" to "fadder," 1.2.1), both associated with Newfoundland pronunciation; and Janet Michael as Ariel lengthened her long "o" and "a" sounds, spoke short " $u$ " sounds as a somewhat lip-rounded "o"-like sound, pronounced some long "i" sounds as "oi," and occasionally changed a short "e" sound for a short "i" sound. The strongest Newfoundland accents belonged to Wade's Stephano and Anonsen's Trinculo; their speech had the same pronunciation features mentioned above, but the actors applied them heavily throughout, which drew plenty of laughter from the theatregoers. The relation between the pair's accents and their buffoonery was established from their first appearance, during their second-act reunion and discovery of Caliban hiding under a blanket. Here, Anonsen switched short "e" sounds for short "i" sounds (e.g., "shed" becomes "shid," 2.2.21), pronounced long "i" sounds as "oi" sounds (e.g., "alive" becomes "aloive," 2.2.25), and stretched out long "a” sounds (e.g., turning "strange" into "straaaange," 2.2.27). Wade did the same, for example turning "devil" into "divil," (2.2.64), "I" into "oi" (2.2.45), and "Marian" into "Maaaarian" (2.2.47). On the recording, the audience 
laughs repeatedly and enthusiastically as the two castaways speak with heavy accents when trying to discover exactly what Caliban was.

The Shakespearean authenticity of performers' deliveries is difficult to quantify. Actors playing three of the principal European characters - Wade doubling as Ferdinand, Kent Barrett as Antonio, Ed Kielly as Alonso - did not speak with Newfoundland accents, but with what approximated mainland Canadian intonations. Charles Tomlinson's Sebastian, meanwhile, spoke with a received-pronunciation British accent. Such accents might have helped mark these villains as outsiders to the island and its ethos, though Sobieski's intonation as Caliban, which was similar to Barrett's and Kielly's, blurred these distinctions. Blurring those distinctions, however, may well have made it more difficult for audiences to perceive Bush's intent to depict the play's Italian aristocrats as English colonizers and Caliban as a colonized Beothuk. Furthermore, Jones and Anonsen did not maintain their pronunciations consistently when playing Prospero and Miranda, respectively; the same is true of Michael, especially when singing Ariel's songs, which she did without a Newfoundland accent. The heavy accents of the drunken Stephano and Trinculo, meanwhile, made them sound less like early modern British imports speaking authentic Shakespearean English and more like rural Newfoundland characters familiar from CODCO sketches about then-contemporary outport-St. John's relations in which speech is a marker of class and urbanity (or lack thereof). ${ }^{35}$ Considering that only part of the cast spoke with Newfoundland accents and that most of them did so intermittently while employing relatively few pronunciation features, which covered relatively few possibly corresponding early modern pronunciations, the similarity between vocalizations in The Nerwfoundland Tempest and Shakespeare's English is partial and approximate. Whether or not that speech somehow redeemed Shakespeare's dialogue by sounding like early modern speech is, therefore, difficult to ascertain. Importantly, what the vocal delivery did instead, besides providing an uneven sorting of characters into Newfoundlanders and others, was to render much of The Tempest in speech that local 
audiences could recognize as something belonging to them. The accents did so in ways that, at times, humorously signalled contemporary concerns about economic disparity in the province, and thereby invited theatre-goers to stake a claim in the production and ownership of Shakespeare as a medium through which Newfoundlanders could speak about themselves to themselves.

While Figgy Duff, too, helped make Shakespearean narrative and characters recognizable and accessible for theatre-goers, much of the band's performance did not signal traditional Newfoundland culture in a straightforward way. This approach is consistent with the band's practice of electrifying traditional Newfoundland culture in a manner characteristic of the cultural revival, making the older rural music appealing to younger urban audiences who listened to British and North American pop songs on radio, television, and recordings. They opened the production with a remarkable evocation of the storm that shipwrecks the characters returning to Italy. The recording captures the tempest starting with low moaning woodwind notes that mimic the wind, the music soon exploding with a drum-and-cymbal crash and a sustained growling electric guitar chord that suggests water smashing the ship. ${ }^{36}$ As the actors speak desperately, the music plays under and between their lines; increasing and lowering their volume, the musicians give the powerful impression of waves tossing a ship up and down. This sonic assault clearly conveyed the characters' peril and was calculated to create suspense when Figgy Duff brought the sound to a terrible crescendo that faded to a low whistle for the peaceful start to the next scene on another part of the island, leaving the voyagers' fates uncertain. The band also provided musical themes - none of which explicitly reworked traditional Newfoundland music - for certain characters that associated them with a particular emotion or trait. For example, the oscillating notes on a plucked mandolin accompanying many of Prospero's lines evoked both his magical powers and a pendulum, suggesting a preoccupation with time; the haunting sound of a hammered dulcimer played for Ariel's appearances indicated that spirit's ethereal nature; and the romantic piano theme that played when lovers Miranda 
and Ferdinand spoke underscored their mutual attraction. Caliban had two themes: one was a slow quiet drumbeat; the other, an ominous piano tune coupled with a propulsive drumbeat, which played during his song of rebellion against Prospero (2.2) and during his final onstage dance after all others departed, evoked his longing for freedom (Bush, "Remembering" 69). Stephano and Trinculo did not have themes, but, in keeping with their strong accents, they were associated with traditional Newfoundland music: an accordion played during Stephano's gruffly sung ribald sea shanty in 2.2; and, when Stephano, Trinculo, and Caliban were pursued by Prospero's avenging spirits in 4.1, reeling accordion music emphasized the pursuit's physical comedy.

If the accordion associated traditional Newfoundland music with the earthy humour of inept servants, music in the masque of the goddesses (4.1) that Prospero conjures to anticipate Miranda's marriage to Ferdinand further demonstrated how the production encouraged local audiences to claim Shakespeare for their own. As Bush's research notes indicate, he regarded Shakespeare's masque - derived from seventeenth-century court entertainments often depicting pastoral settings that ended in a dance between performers and spectators - as a respite from the action temporarily suspending the drama's plot. He also considered the masque an interlude that offered specific lessons. In Bush's version of the scene, Prospero magically compelled his usurping brother Antonio and the villainous Alonso and Sebastian to perform the parts of Iris, Ceres, and Juno. The actors spoke the goddesses' lines accompanied by a keyboard tune that sounded like church-organ music; the lesson was that they should feel powerless as Prospero had when he was exiled to the island. Pamela Morgan, the lead singer of Figgy Duff, sang Ceres's blessing of Miranda and Ferdinand (accompanied by another dignified keyboard tune), the lesson being that the men should become aware of their inherently feminine traits. Together, these lessons would help the men acquire empathy, though the specifics of such lessons would have been difficult to discern in performance, especially since they did not feature in the program or the publicity. Theatre-goers would have seen three men compelled by Ariel's magic 
to speak the goddesses' lines, which they did in a broadly comical way to induce laughter at their characters' suffering. ${ }^{37}$

The next phase of the scene gave audience members the chance literally to "relocate themselves at the centre of the stage" (Rix 236), thereby making contemporary Newfoundland part of the production in an exciting way. Figgy Duff struck up a traditional Newfoundland number, a lively two-minute reel on mandolin, accordion, and drums. After Iris calls for nymphs and reapers - typical pastoral figures from the masque - to join the celebrations, theatre-goers joined the actors on stage for a dance. Bush's research notes suggest that, early on, he thought about this participation as a lesson that would prepare Antonio, Alonso, and Sebastian to be forgiven their sins, though he also believed that Prospero does not fully forgive them until the play's final scene. ${ }^{38}$ That is, by allowing local theatre-goers to participate joyfully in the masque, the interlude might be read as a way to reclaim Shakespearean performance and the elite court genre of the masque embedded within it as a Newfoundland tradition through which the transgressions of the male European rulers that Bush associated with predatory capitalism could be redeemed. However, that kind of lesson is not as obvious as the thrill of the dance was. The recording captures the noise of excited audience members mounting the stage; moments later, the music resumes with plenty of loud clapping, stomping, and "whoos!" from the theatre-goers. The sounds of dance and traditional Newfoundland music continue for almost three minutes, after which sustained loud applause joins the cheers. The recording thus makes it clear that for this audience the dance was a way to be, if not protagonists, then participants, and thereby make this Shakespearean performance theirs, at least a for short time. However, the scene also helped fulfill the publicity's portrayal of the show: the dance delivered on the promise of "music," "rowdiness," and a "spirited jig," and, according to one reviewer, Jones's Prospero enjoyed a "Black Horse" beer during the scene (Moores).

Reviews of the production do not suggest that critics perceived Bush's lessons in the masque, but they took seriously his efforts to make Shakespeare accessible by giving The Tempest a Newfoundland 
identity. There was consensus about Figgy Duff, whom every critic praised unreservedly: their music was central to the show's "Newfoundland perspective" (Moores), "it inspired audience participation because it was something" local theatre-goers "were familiar with," and it thus "bridged the gap between [them] and the characters on stage" (Rimsay 21). Marilyn Duffett, in Nerwfoundland TV Topics, asserted the interaction was necessary because the play's "language demands close attention" that theatre-goers supposedly did not possess (9). Others concurred that the show "reminds us that Shakespeare is not stuffy" (Rimsay 21) and that is it not "of the dusty Shakespeare variety - it's full of Newfoundland culture bye" (Moores). Notably, critics largely ignored issues of class and colonialism, which is not entirely surprising, given that the significant publicity preceding the show downplayed Bush's political intentions and that neither the photographs nor the recording indicates that audiences could have read Caliban unambiguously as Beothuk. The result is that The Newfoundland Tempest was not explicitly understood - at least, not outside the theatre - as, partly, a narrative of capitalist-imperialist depredations. Instead, most reviews discussed performers' Newfoundland accents, and critical disagreement about the accents was couched in the same terms of Shakespearean authenticity Bush employed. The Globe and Mails Ray Conlogue, for example, credited the notion that Newfoundland pronunciation was close to Shakespeare's and that it could save the playwright's poetry from the "flat" speech of most North Americans, while Karl Moores, writing in the student newspaper The Muse, argued that the accents altered Shakespeare's intended characterization, and Duffett, remarking on the inconsistency of performers' accents, questioned the historical validity of linking local and Shakespearean speech and the appropriateness of using such speech for The Tempest (10). However, these three critics all agreed about the appropriateness of either Anonsen's and/or Wade's accents for Trinculo and Stephano, respectively, underlining their perceived connection between easily identifiable Newfoundland speech and Shakespeare's inebriated servants whose rebellion against their masters fails laughably. 
While these comments explicitly celebrate the production's humour, which the audience on the recording enjoyed and which helped make Shakespeare accessible, such reception implicitly, and apparently unintentionally, endorses a view of the show's thickly accented Newfoundlanders as naive and unable to wield power.

Only in the limited national media exposure that The Tempest received was there any explicit concern with how the production reflected Newfoundland's relationship to central Canada. After chastising "the Newfoundland actor" in general for lacking "[ $t]$ enderness" - without which "Shakespeare is nothing" - Conlogue speculated that the actors' perceived failings were due to Bush being "over-awed by the quaintness of his company, and let[ting] them do pretty much what they pleased onstage." Conlogue regarded such attitudes as "a form of paternalism which cheats the Newfoundland actor, and his [sic] audience, of the artistic emergence which is potentially there." There is an irony in a Toronto-based critic who condescendingly judges all Newfoundland actors and then accuses a Toronto-based director of patronizing his cast by not disciplining them sufficiently in a production meant to redeem Shakespeare through Newfoundland culture. Yet, Conlogue's comment recognizes that this Tempest's hierarchical mode of production is grounded in the belief that the director - in this case, one from Toronto - assumes central responsibility for artistic choices and therefore must assert the authority of his position by instructing Newfoundlanders on how to channel their identity through supposedly acceptable forms of Shakespearean theatre.

Bush was clearly aware of the implications in this relationship. In a letter to the CBC's Sue-Anne Kelman, Bush comments that, being from Toronto, he did not coach his Newfoundland cast on their accents, as Kelman had suggested on the national radio broadcast "Sunday Morning," though he did encourage them to speak with their own accents. He was concerned that such misconceptions would contribute to many Canadians' sense of grievance against the media and politicians in Toronto and Ottawa. Kelman, too, acknowledged the regional cultural politics at stake in her misspoken words, assuring Bush that 
"[n]o centrist slur was implied." While Bush sent a copy of this correspondence to the RCA, apparently to assure them that he did not claim credit for coaching Newfoundland actors on their own speech patterns, local reviewers expressed little interest in his role. Few critics mentioned Bush by name, only Mary Dalton and Paddy Warwick attributed any artistic responsibility for the production to him, and no reviewer indicated he was from Toronto. ${ }^{39}$

The differences between local and national reception perhaps reflect the way that The Nerwfoundland Tempest adjusted concerns typically associated with the cultural revival. The production's director did partly reframe traditional Newfoundland culture in terms of theatrical norms and dramatic literature from outside the province in a manner analogous to, say, Memorial University scholars using methodologies and critical concepts that belonged to a North American and European modern academy to frame Newfoundland culture as pre-modern or traditional. Nevertheless, the production signalled to its St. John's audiences that the show was of Newfoundland, especially through accented speech and much of the music. The accents conveyed perhaps simplified ideas of Newfoundland identity and Shakespearean authenticity, and the nuances of Bush's complex understanding of the masque may not have been obvious in performance. Still, that masque, with its lively traditional music and raucous participatory dance, was a straightforward means for local theatre-goers to claim and co-create, through their own physical performance, an entertaining and popular version of Shakespeare as an expression of Newfoundland culture. It was an attitude of traditional connection with and shared ownership of Shakespeare that would reappear in approaches to staging the author's work in the province three decades after The Nerwfoundland Tempest closed.

\section{After The Newfoundland Tempest}

There is little evidence that the 1982 Tempest's reworking of Shakespeare to make his plays more specifically about Newfoundland inspired other local practitioners to do the same in the short term. Memorial 
University's Drama Society (MUN Drama) began staging Shakespeare later in 1982 and continued to do so until 1996. Under the leadership of the English Department's Gordon Jones, MUN Drama was a training ground for many of the province's most accomplished theatre practitioners and it provided some of them with a model for how to run a summertime Shakespeare festival. However, none of the publicity material or reviews for these shows indicate that those who staged these summertime productions made concerted efforts to locate Shakespeare's work in Newfoundland, at least not until the Society's 1995 Comedy of Errors, which was set at the St. John's Regatta. As Michael Nolan, who took part in many MUN Drama productions, recounts, the group was motivated initially by economics, since the long-dead playwright collects no royalties (89). Furthermore, Nolan regards the years-long run of Shakespeare performances not as a way to develop a Newfoundland culture but as an opportunity for students to learn how to produce theatre (89). Similarly, the Newfoundland Shakespeare Company (NSC), founded by Michael Wade, began with a production of Hamlet at the LSPU Hall two years after The Newfoundland Tempest. Yet, Wade chose to produce Shakespeare because of the playwright's prestige and because he wanted to "work with the best available" (Walsh 10). He understood the NSC, which produced seven Shakespeare plays between 1984 and 1989, in the same way Nolan regarded MUN Drama - as a means to professionalize local actors through Shakespearean performance (Walsh 10).

Although MUN Drama and the NSC, the two organizations that established regular Shakespeare performance in Newfoundland and Labrador, did not approach the playwright's work as a means for extending the cultural revival, The Nerwfoundland Tempest did have an afterlife. In 1983, Figgy Duff released their album, After the Tempest, which included music from the production, and Pamela Morgan eventually transcribed and notated the music from an audio recording of the original staging. Versions of this music were incorporated into Tempest productions in 2006 and 2009 (Morgan 73), and in 2013 Morgan re-recorded the score, releasing it as an album and making "a theatre 
version available for license" (Morgan 74). In 2015, the ACC toured "Sounds and Sweet Airs," which combined a live performance of the score with dialogue from the play. ACC publicity noted the production's roots in the 1982 staging and echoed sentiments attached to the original production by commenting that it would interest "Newfoundlanders who can marvel at how perfectly our musical traditions integrate into the work of the world's most famous playwright" ("Sounds").

In the 1990s, a generation of theatre artists in St. John's began staging Shakespeare outdoors to draw connections between the landscape and the playwright's work, but it was not until 2010 that practitioners overtly explored the kinds of ideas that motivated The Newfoundland Tempest. ${ }^{40}$ That year saw the establishment of the New World Theatre Project (NWTP), a company that built a replica Jacobean playhouse at Cupids to commemorate the community's 400th anniversary. NWTP co-founder Aiden Flynn relates that, although the company did not explicitly emulate the aims of The Newfoundland Tempest, the production was part of the St. John's theatre community's "mythos" and that he discussed the show with Andy Jones, who has performed with NWTP since its beginning. ${ }^{41}$ Still, the company's prospectus is remarkably similar to Bush's proposal. It announces that NWTP's inaugural season would "celebrate the theatre and stories of John Guy's England" (3), and, in a twist on Bush's view that The Tempest's villains are analogous to exploitative West Country merchants, the prospectus evinces the company's interest in "the spirit of exploration and discovery" and those "English entrepreneurs and nobility [who] looked westward across the ocean to seek their fortune" (4). By staging "dramatic work that explores the experience of the English in Newfoundland over 400 years," the company intended to locate Newfoundland identity partly "in the cultural experience" John Guy's "settlers ... brought with them to the New World" $(5,7)$.

These sentiments encourage a belief in a centuries-long chain of cultural transmission, suggesting that performance in a remodelled seventeenth-century theatre is a way to make contact with the island's early European inhabitants. Since its first season, NWTP, which 
rebranded as Perchance Theatre in 2014 under Danielle Irvine's artistic directorship, has continued in this vein. By setting Shakespeare productions in seventeenth- and eighteenth-century Newfoundland, directing actors to speak in local accents, and repeatedly publicizing the ways that Cupids' rural location and history enhance Shakespearean performance, the company has implicitly carried out the work of Bush's proposal while insisting on connections between early modern culture, landscape, and Newfoundland identity. ${ }^{42}$ In 2016, Jillian Keiley's As You Like It at Ontario's Stratford Festival reframed the work of making Shakespeare part of the island's cultural inheritance, but rather than depicting early modern settlers she located the action in rural Newfoundland circa 1985 during the cultural revival. ${ }^{43}$ Keiley thus sought to revive the province's traditional culture, which she describes in her director's notes as "not performative but participatory" (9). Encouraging audiences to join the performance by waving props stowed under their seats symbolizing the ocean, sheep, and sky, she regarded performance at Canada's principal Shakespearean theatre as an opportunity for spectators to embody the democratizing spirit of the cultural revival by "being a part of a kitchen-party culture, a dance-together culture"(9). Like Flynn and Irvine, Keiley knew about The Newfoundland Tempest by its reputation and by discussing it with Jones and Morgan, and although she did not consciously imitate the 1982 production in As You Like It,$^{44}$ Keiley did conclude her show with a participatory episode reminiscent of Bush's masque: the deity Hymen invited audience members onstage to celebrate the play's nuptials with cast members by taking part in the traditional Newfoundland dance, "Running the Goat."

The recent efforts of theatre artists to revive an image of traditional Newfoundland through Shakespeare is reminiscent of $A$ Midsummer's Nightmare, where the revolutionaries'encounter with the political ghosts of the island's past serves as inspiration for coping with its future, but Keiley's retrospective production is a reminder of how The Nerwfoundland Tempest formulated the relationship between ideas about urban modernity and rural premodernity. Keiley's staging of As You Like It is especially similar to the 1982 Tempest insofar as it drew on the prestige 
of the playwright (plus that of the Stratford Festival) to endorse the notion that Newfoundland culture is, at root, democratic and rural. The two productions, that is, reframed ideas about traditional Newfoundland through elite forms of modern theatre, the later one staged at Canada's busiest venue for theatre-festival tourism. While The Nerwfoundland Tempest was, in 1982, exceptional for its approach to Shakespeare, the tensions this production embodied - those between a traditional Newfoundland society and a modern conceptual-artistic framework were inherent to the cultural revival. These tensions structured the development of Newfoundland Studies at Memorial University; they were evident in much political theatre during the 1970s when urban artists reflected current social issues to rural audiences through contemporary forms of performance; and they were at work in CODCO's reframing of the cultural revival's satirical theatre on CBC television. Importantly, these tensions characterized the reform of collectively created performance and the rise of professional theatre staged at the LSPU Hall under the auspices of the RCA, which was governed in accordance with the principles of the Canada Council. The Nerwfoundland Tempest was, thus, of its time as an exponent of the cultural revival and as a product of the changes in St. John's professional theatre. While few followed the production's specific example in the short term, its use of Shakespeare to articulate Newfoundland identity — and that identity as a way to "redeem" Shakespeare - is an approach that has become particularly influential in the province in the last 10 years.

\section{Acknowledgements}

An early draft of part of this article was presented at the 2019 British Shakespeare Association conference. Thanks to participants in the "Shakespeare and the Margins" seminar for their commentary on that work. We thank the anonymous readers for $N L S$, Jeff Webb, and Ágnes Juhász-Ormsby for their insightful feedback on this article, which allowed us to improve it significantly. We are grateful to staff at Memorial University's Archives and Special Collections and at the 
L.W. Connolly Archives at the University of Guelph for their help locating research material. Thanks to the Social Sciences and Humanities Research Council of Canada, which helped fund research for this article.

\section{Notes}

1 The LSPU Hall in St. John's "was formerly owned by the Longshoreman's Protective Union" and currently has "a 175-198 seat theatre" upstairs and smaller performance space on its main floor (http:// 1spuhall.ca/about). The Resource Foundation for the Arts (RFA) purchased the LSPU Hall in 1976; in 1979, the Resource Centre for the Arts assumed ownership of the facility.

2 Sandra Gwyn widely circulated the term in the April 1976 issue of Saturday Night magazine. See Joan Sullivan's annotated version.

3 For accounts of such appropriations and related critical debates, see Loomba 161-68; Rix.

4 The Mummers Troupe staged Bush's puppet show Once a Giant (1974); he acted in their East End Story (1975) and directed their Dying Hard (1975) (Brookes, A Public 236-37).

5 Figgy Duff played in CODCO's 1975 Das Capital at the ACC. See CODCO 137.

6 Similarly, Lynde comments on St. John's theatre in 1988-89: “The recent interest in scripted plays suggests that there is a growing interest and reliance on the director as artist rather than as actor/ manager or producer" ("The 1988-89" 695).

7 For more on Shakespeare in Newfoundland and Labrador, see Ayers "Learning" and "Shakespeare”; King and Ormsby; Ormsby, ed.; and Schweitzer. For more on St. John's theatre, see Ferry; Gulliver 205-49; all entries by Lynde; Lynde, Peters, and Buehler; and Peters, "Introduction" to Stars. For more on the RCA, see Locke, "A Brief"; and Filewod's "The Mummers" and "Writing." For another perspective on Newfoundland and Labrador's theatre, see the STAGE project (www.mun.ca/STAGE).

8 We are not making categorical distinctions between imported and domestic Newfoundland culture. Practices such as mummering were imported to Newfoundland but were clearly domesticated there over 
many decades. But the same is true of other cultural forms, such as popular American music, and media, such as radio (Webb, "Repertoire"). The point is that many who have construed traditional, authentic Newfoundland society as isolated have done so using concepts and media that are not exclusively rooted in that domestic culture. This valorization of the island's past in identifying rural traditions that could instill beliefs about an authentic Newfoundland character in the present extends earlier versions of a "nationalist outlook" (Bannister, "Whigs and Nationalists" 87). For pre-1970s efforts to prevent cultural loss, see Gulliver 155-56; Webb, "Constructing" 167; Bannister, "Making History" 180; Overton, "Sparking” 196-98. The kinds of debate about Newfoundland regionalism in the 1960s and 1970s that linked economic development and interest in folk traditions were at that time "common to a very large number of areas in North America and Europe" (Overton, "Towards" 221-22, 229; see also Gulliver 19-20). Anti-materialist strains of Newfoundland regionalism "paralleled and connected with ... the counter-cultural movement of the 1960s" (Overton, "A Newfoundland" 8), and artists of the cultural revival were influenced by politically committed theatre and music originating in Canada, the United States, and England (Gulliver 163-64, 208, 210, 244; Peters, "Introduction" to Stars xiii). See also McKay.

9 Pocius's view is, perhaps, contentious. Nevertheless, such reframing of traditional culture is evident, for example, in the research leading to the Dictionary of Newfoundland English; the repurposing by Sheila's Brush of "Jack" folktales in a play such as Jaxxmas (1979), which was set in contemporary St. John's and premiered at the LSPU Hall; and Figgy Duff, which frequently played to urban audiences. Still, Memorial's Extension Service served numerous areas of the province and Sheila's Brush and Figgy Duff also performed outside St. John's.

10 Two prominent examples of such institutions serving urban audiences are the LSPU Hall and Memorial University's Art Gallery. For more on the Art Gallery, see Gulliver 103-29. Thanks to Jeff Webb for access to drafts of his work on the Art Gallery's history.

11 For more on the relationship between local artists and the ACC, see Gulliver 55-62. 
12 The most thorough accounts of The Mummers are Brookes's A Public and "The Mummers" and Filewod's "The Mummer's" and "Writing." Helen Peters's "Introduction" to The Plays and "From Salt Cod" are the lengthiest scholarly treatments of CODCO. For more on CODCO, see Gard; Goldie, “The Rock”; Lynde, "CODCO”; and Porter. Skidmore, 191-95, discusses The Mummers and CODCO. The only piece written on the NTTC is Farquharson's.

13 See the essays in Halpert and Story for accounts of the history of mumming in Newfoundland.

14 These agencies are the Canada Council, the Community Planning Association of Canada, and Oxfam (Brookes, A Public 128-38, 162-75).

15 Filewod covers these events in "The Mummers." See also Gulliver 232-34; Locke. The Canada Council intervened previously to try to unify companies within the fractious St. John's theatre community. See Filewod 12-13 on the report Keith Turnbull wrote for the Council and on efforts by the agency's David Peacock to encourage CODCO, the Mummers, and the NTTC to submit a joint funding application to the Council.

16 Artists wanted the committee to decide if the company could maintain residency in the building and to "divide the assets of The Mummers and the RFA" (Public Meeting; see also Filewod, "The Mummers" 28-31).

17 The committee determined that The Mummers should be separated from the RFA and that the company had a right to continue to use the LSPU Hall (Report 1-2; Filewod, “The Mummers” 30). They made this decision by following the rationale of funding agencies like the Canada Council that such agencies give money to theatre companies rather than "to the support of buildings or centres" and that Council funding to The Mummers indicated the company's development of the LSPU Hall (Report 2; Filewod, "The Mummers" 30). The report is bureaucratically precise in its distribution of resources and responsibilities (Report 3-5; Filewod, “The Mummers” 30).

18 Filewod argues The Mummers' situation was not unique but paradigmatic: "To the extent that the underlying crises of Canadian culture were exposed within the internal operations of the company by its refusal to accept the Canada Council's terms of containment, the 
Mummers Troupe was the typifying expression of Canadian theatre in the 1970s" (31).

19 The Mummers performed the Traditional Newfoundland Mummers Play for more than a dozen communities outside St. John's on each of their 1979-80 and 1981 school tours. For performance and tour records, see Coll. 126 (4.20.007-013), Archives and Special Collections, Memorial University of Newfoundland, St. John's, NL.

20 See, for instance, their collectively authored Jaxxmas. The company performed in St. John's and toured productions across the province: between 1980 and 1983, their children's tours, co-produced with the RCA, reached over 14,000 spectators (RCA Attendance).

21 Not all these tours were within Newfoundland, and most were in urban areas, but even The Mummers, who toured to many small communities in Newfoundland, often performed in larger centres on the island (including ACCs in Grand Falls, Corner Brook, and Stephenville) and toured across Canada between 1973 and 1981. See records in Coll. 126 (4.03-4.23), Archives and Special Collections, Memorial University of Newfoundland, St. John's, NL.

22 During the 1960s and 1970s, amateur companies in the city staged a range of productions: children's shows; musicals; Broadway comedies; serious twentieth-century drama by major European playwrights; and recent drama about Newfoundland and its diaspora by Tom Cahill, Michael Cook, and David French. This information is derived from the finding aid spreadsheet for the poster and handbill collection, Coll. 138, Archives and Special Collections, Memorial University, St. John's, NL. The professional London Theatre Group had a comparably variable repertoire when it was resident in St. John's during the 1950s (Yeo), as did the Newfoundland Travelling Theatre Company when it staged shows professionally in the 1970s (Farquharson). These companies coexisted with the St. John's Symphony Orchestra and local Kiwanis organizations, and they staged shows at the same time that the Canadian Opera Company, Ontario's Stratford Festival, and the National Ballet of Canada toured to St. John's.

23 See also Locke 3-4.

24 Newfoundland companies and artists who performed there include The Mummers, Rising Tide Theatre, MADCAP Comedy, the St. John's 
Symphony Orchestra, Ron Hynes, Sandy Morris, and Figgy Duff. The Irish Newfoundland Society presented Irish dramatist Brendan Behan's The Hostage. Mainland Canadian artists include The Mulgrave Co-op (Nova Scotia), Theatre Network (Alberta), and folksinger Valdy (Ontario). This information comes from microfilm of The Evening Telegram.

25 Besides their own shows, they hosted local musicians and housed productions by Newfoundland theatre companies staging Newfoundland authors' plays (RCA Attendance). These are Sheila's Brush, Rising Tide, The Mummers Troupe, Chris Brookes, Rare Vintage Theatre, Solo Theatre, Theatre Newfoundland, Developmental Theatre for the Deaf, Newfoundland Dance Theatre, and Wonderbolt Circus. LSPU Hall audiences watched plays by Newfoundlanders Tom Cahill, Al Pittman, Michael Cook, CODCO, Michael Wade, and Doreen Ayre. They could attend concerts sponsored by the Newfoundland Irish Association, and those featuring Newfoundlanders Émile Benoit, Kelly Russell, and Figgy Duff. This information comes from microfilm of The Evening Telegram. The RCA served the local community by running cabarets, student shows, dances, and workshops, but they also hosted the 1981 Atlantic Film Festival, ran festivals celebrating the Portuguese in Newfoundland, and staged and screened numerous plays and films by Canadian and international dramatists and filmmakers (RCA Attendance).

26 Information in this paragraph comes from microfilm of The Evening Telegram. Children's performers from Newfoundland and Canada offered theatre, music, and puppetry. The St. John's ACC, the Newfoundland Museum, Memorial University of Newfoundland Art Gallery, and other groups at the university screened films on artists and Newfoundland history, children's films in English and French, and classic Hollywood and contemporary European cinema. The ACC served its urban constituency - renting space to local music festivals, school groups, and dance studios - and brought in performers and spectacles that could fill its main auditorium. Microfilm of The Evening Telegram indicates these include the Miss Canada pageant; popular musicals by amateur groups; Reveen the magician; Agatha Christie mysteries; Vera Lynn; the Vienna Boys Choir; Oscar Peterson; and The Chieftains. 
27 Microfilm of The Evening Telegram indicates the Wonderful Grand Band played the St. John's ACC in the summer of 1980 and at the Hall six months later; Figgy Duff performed repeatedly at both venues; in 1981, the RCA transferred its Terras de Baccalbau to the St. John's ACC and three months later held a benefit show there with the Sheila's Brush Dancers; and in 1982, The Mummers' Makin'Time With the Yanks, which ran one year earlier at the Hall, toured the ACCs.

28 The RCA's Tempest may represent a respite from arguments among St. John's artists over the issue of non-Newfoundlanders portraying Newfoundland subjects (Filewod, “The Mummers" 20-21), but whether or not its Tempest helped align Newfoundland theatre practices with those in the rest of Canada is difficult to determine; it is a question best assessed in relation to the totality of other public presentations offered at the time in the province.

29 For a similar recapitulation of the history of Shakespearean theatre in Newfoundland and Labrador on which this account relies, see Ormsby, "Introduction" 1-3.

30 According to the play's poster, Sheila's Brush presented it with the Rangoon Opera Co. and Acme Talent Academy and produced it with funding from the Canada Council, The Newfoundland and Labrador Arts Council, Claws Comedy, and the RCA. A Midsummer's Nightmare played in Bannerman Park 9-13 July and at the LSPU Hall 15-20 July (Evening Telegram, 4 July 1980).

31 In an e-mail, Bush relates his thinking about such issues was influenced by Toronto Workshop Productions' 1969 Tempest in which he played Prospero.

32 They are in Coll. 125 (7.09.036), Archives and Special Collections, Memorial University of Newfoundland, St. John's, NL.

33 Coll. 125 (10.01.072), Archives and Special Collections, Memorial University of Newfoundland, St. John's, NL.

34 For more on the historical features of English in Newfoundland and Labrador, see Dialect Atlas of Nerwfoundland and Labrador: https:// dialectatlas.mun.ca.

35 See, for example, Scene 13 (192-98) of CODCO's Das Capital.

36 Thanks to Pamela Morgan for information about the production's music and instruments. 
37 Thanks to Pamela Morgan for relating this detail.

38 Thanks to Steven Bush for e-mail correspondence clarifying his approach to the masque.

39 Bush's letter is in the L.W. Connolly Archives at the University of Guelph, XZ1MSA139, Box 13. A copy of Kelman's letter is in Coll. 125 (7.09.036), Archives and Special Collections, Memorial University of Newfoundland, St. John's, NL.

40 For an account of such work, see Irvine. She portrays outdoor Shakespeare from the 1990s onward as a way to make the author's plays meaningful to local audiences by drawing connections between text and landscape. For more on what Bannister calls the "surge in nationalist sentiment within the province's arts community" in the 1990s (137), see his "The Politics" 137-39. For more on recent fiction that treats connections between Newfoundland and Labrador identity and landscape, see Chafe "'a terrain" and "Entitlement"; and Sugars. Comparable work on drama in the province remains to be done.

41 Thanks to Flynn for relating these details. Full disclosure: both authors have worked with Flynn and Irvine.

42 Irvine's knowledge of The Newfoundland Tempest is by word of mouth. While her work is not overtly influenced by that knowledge, she shares the aims of the 1982 production. Thanks to Irvine for relating these details. For more on how Perchance publicizes such connections, see its home page (https://www.perchancetheatre.com), its "History" page (https://www.perchancetheatre.com/our-history.html). See Perchance's Sustainability Project (9-71) for audiences' and locals' shared belief in the company's efforts to connect early modern culture and contemporary Newfoundland and Labrador identity.

43 For more on this production and Shakespeare at Cupids, see Ormsby's forthcoming 2021 essay about it.

44 Thanks to Keiley for relating this information. 


\section{Works Cited}

A Midsummer's Nightmare Poster. 8-13 July 1980. Coll. 143. Archives and Special Collections, Memorial University of Newfoundland, St. John's, NL. http://collections.mun.ca/cdm/ref/collection/a_posters/id/2967. Accessed 25 May 2018.

Arts and Culture Centre. Press Release. 15 Feb. 1982. Coll. 125 (7.09.036).

Archives and Special Collections, Memorial University of Newfoundland, St. John's, NL. Accessed 11 May 2018.

Ayers, Peter. "Learning to Curse in Accurate Iambics: Shakespeare in Newfoundland." Shakespeare in Canada: "A World Elsewhere?", edited by Diana Brydon and Irena Makaryk, U of Toronto P, 2002, pp. 192-211.

. "Shakespeare in St. John's.” Canadian Theatre Review, vol. 54, Spring 1988, pp. 34-38.

Bannister, Jerry. "Making History: Cultural Memory in Twentieth-Century Newfoundland." Newfoundland and Labrador Studies, vol. 18, no. 2, 2002, pp. 175-94.

. "The Politics of Cultural Memory: Themes in the History of Newfoundland and Labrador in Canada, 1972-2003.” Collected Research Papers of the Royal Commission on Renewing and Strengthening Our Place in Canada. Government of Newfoundland and Labrador, 2003, pp. 119-66.

- "Whigs and Nationalists: The Legacy of Judge Prowse's History of Newfoundland." Acadiensis, vol. 32, 2002, pp. 84-109.

Brookes, Chris. A Public Nuisance: A History of The Mummers Troupe. ISER Books, 1988.

- "The Mummer Troupe." Proceedings of the Workshop on Nerwfoundland Theatre Research, edited by Denyse Lynde, Helen Peters, and Richard Buehler, Memorial University of Newfoundland, 1993, pp. 119-27. Bush, Steven. E-mail correspondence. 2 May 2020.

. "George Luscombe Directing Chicago'70 at Toronto Workshop Productions: An Insider's Subjective Account.” Theatre Research in Canada/Recherches théâtrales au Canada, vol. 36, no. 1, 2015, pp. 156-64. - Letter to Sue-Anne Kelman. XZ1MSA, Box 13, L.W. Connolly Archives, University of Guelph Library, Guelph, ON. Accessed 7 June 2018. 
"Proposal for a Newfoundland 'Tempest'.” Coll. 240 (3.38.001).

Archives and Special Collections, Memorial University of Newfoundland, St. John's, NL. Accessed 25 May 2018.

- "Remembering the Nfld. Tempest, 35 Years On." Brave New Worlds: Shakespeare in Newfoundland and Labrador, edited by Robert Ormsby, Memorial University Libraries, 2018, pp. 68-72. Memorial U of Newfoundland Digital Archives Initiative, collections.mun.ca/cdm/ compoundobject/collection/qeiipublic/id/465/rec/1. Accessed on 4 November 2019

- Research notes for The Newfoundland Tempest. XZ1MSA, Box 13, L.W. Connolly Archives, University of Guelph Library, Guelph, ON. Accessed 7 June 2018.

Chafe, Paul. '“a terrain of jagged, fearful aspect': Reconsidering Patrick Kavanagh's GaffTopsails." Newfoundland and Labrador Studies, vol. 31, no. 1, 2016, pp. 37-77.

- "Entitlement, Anxiety of Possession, and (Re)Working of Place in Michael Crummey's Sweetland." Nerwfoundland and Labrador Studies, vol. 32, no. 1, 2017, pp. 7-41.

CODCO. The Plays of CODCO, edited by Helen Peters, Peter Lang, 1992. . "Das Capital: Or What Do You Want To See the Harbour For Anyway?" The Plays of CODCO, edited by Helen Peters, Peter Lang, 1992, pp. 137-99.

Conlogue, Ray. "Magic Is Missing in Newfoundland Tempest." Globe and Mail, 17 Feb. 1982, p. 11.

Dalton, Mary. "Rich in Words, Dance, Music, and Costume." The Newfoundland Herald, 20 Feb. 1982, pp. 52-53.

The Dialect Atlas of Newfoundland and Labrador. Memorial University of Newfoundland, 2012. dialectatlas.mun.ca/.

Draft Revision of the Articles of Association of the Resource Centre for the Arts. St. John's, NL. 22 Nov. 1979. Coll. 126 (2.03.001). Archives and Special Collections, Memorial University of Newfoundland, St. John's, NL. Accessed 21 Sept. 2018.

Duffett, Marilyn. “The Tempest.” Nerwfoundland TV Topics, 20 Feb. 1982, pp. 9-10. Farquharson, Danine. "Newfoundland Travelling Theatre Company (NTTC)." Heritage Nerwfoundland and Labrador, 2001, www.heritage. nf.ca/articles/arts/newfoundland-travelling-theatre-company.php. Accessed 1 June 2019. 
Ferry, David. "The Development of Professional Theatre in St. John's 1967-1982: A Personal Perspective." Theatre Research in Canadal Recherches théatrâles au Canada, vol. 26, nos. 1-2, 2005, pp. 142-55.

Filewod, Alan. "Writing The Mummers Troupe: Historiography and Me."

Proceedings of the Workshop on Newfoundland Theatre Research, edited by

Denyse Lynde, Helen Peters, and Richard Buehler, Memorial

University, 1993, pp. 29-34.

- "The Mummers Troupe, the Canada Council, and the Production of

Theatre History." Theatre Research in Canada/Recherches theâtrales au

Canada, vol. 19, no. 1, 1998, pp. 3-34.

Gard, Peter. "The Look-Homeward Angle: 20 Years of CODCO." Arts Atlantic, vol. 47, 1993, pp. 36-38.

Goldie, Terry. Review of A Midsummer's Nightmare. CBC Radio, 16 July 1980. . "The Rock and the Mainland." Canadian Theatre Review, vol. 59, 1989, pp. 80-83.

Gulliver, Mekaela. Preserving the Best: Nerwfoundland's Cultural Movement, 1965-1983. 2014. Memorial University of Newfoundland. PhD dissertation. research.library.mun.ca/8227/1/thesis.pdf. Accessed 10 May 2018.

Gwyn, Sandra. "The Newfoundland Renaissance." Annotated and footnoted by Joan Sullivan. Nerwfoundland Quarterly, vol. 103, no. 3, 2010, pp. 38-54.

Halpert, Herbert, and G.M. Story. Christmas Mumming in Newfoundland. Toronto: U of Toronto P, 1969.

Irvine, Danielle. "Shakespeare by the Sea's Two Tempests." Brave New Worlds: Shakespeare in Newfoundland and Labrador, edited by Robert Ormsby, Memorial University Libraries, 2018, pp. 105-07. Memorial U of Newfoundland Digital Archives Initiative, collections.mun.ca/cdm/ compoundobject/collection/qeiipublic/id/465/rec/1. Accessed on 4 November 2019

Keiley, Jillian. "Director's Notes: Setting As You Like It in 1980s Newfoundland." As You Like It Program at the Stratford Festival, Stratford, ON, 2016, p. 9.

Kelman, Sue-Anne. Letter to Steven Bush. 25 Feb. 1982. Coll. 125

(7.09.036). Archives and Special Collections, Memorial University of Newfoundland, St. John's, NL. Accessed 11 May 2018.

King, Michelle. "A Timeline of Shakespeare in Newfoundland and Labrador." Brave New Worlds: Shakespeare in Nerwfoundland and Labrador, edited by 
Robert Ormsby. Memorial University Libraries, 2018, pp. 136-45.

Memorial U of Newfoundland Digital Archives Initiative, collections. mun.ca/cdm/compoundobject/collection/qeiipublic/id/465/rec/1.

Accessed on 4 November 2019

_ and Robert Ormsby. "Florence Glossop-Harris (1883-1931) at the Casino Theatre: Touring the London Stage to St. John's." Newfoundland Quarterly, vol. 110, no. 1, 2017, pp. 36-43.

Locke, Fran. "A Brief History of the LSPU Hall." Inventory of the Papers of Resource Centre for the Arts Coll. 125. Arranged and described by Gail Weir, pp. 3-4. Centre for Newfoundland Studies, Memorial University of Newfoundland, St. John's, NL. Accessed 11 May 2018. Loomba, Ania. Shakespeare, Race, and Colonialism. Oxford UP, 2002. Lynde, Denyse. “CODCO.” The Canadian Encyclopedia. www.thecanadianencyclopedia.ca/en/article/codco. Accessed 10 May 2019. "Collective Creation." Heritage Newfoundland and Labrador. www. heritage.nf.ca/articles/arts/collectives.php. Accessed 10 May 2019. - "Professional Companies." Heritage Newfoundland and Labrador. www.heritage.nf.ca/articles/arts/professional-theatre-companies.php. Accessed 10 May 2019.

. "Theatre." Heritage Nerwfoundland and Labrador. www.heritage.nf.ca/ articles/arts/theatre.php. Accessed 10 May 2019.

. "The Newfoundland Collectives: The Wake or the Awakening?" Canadian Theatre Review, vol. 55, 1988, pp. 48-52.

. “The 1988-89 St. John's Theatre Season.” Queen's Quarterly, vol. 96, no. 3, 1989, pp. 691-97.

, Helen Peters, and Richard Buehler, editors. Proceedings of the Workshop on Newfoundland Theatre Research. Memorial University of Newfoundland, 1993.

McKay, Ian. Quest of the Folk: Antimodernism and Cultural Selection in Twentieth-Century Nova Scotia. McGill-Queen's UP, 1994.

Moores, Karl. “William Shakespeare in Oilskins?” The Muse [St. John's], 19 Feb. 1982.

Morgan, Pamela. "Sounds and Sweet Airs: An Original Score for Shakespeare's The Tempest by Figgy Duff." Brave New Worlds: Shakespeare in Nerwfoundland and Labrador, edited by Robert Ormsby, Memorial University Libraries, 2018, pp. 73-74. Memorial U of Newfoundland 
Digital Archives Initiative, collections.mun.ca/cdm/compoundobject/ collection/qeiipublic/id/465/rec/1. Accessed on 4 November 2019 New World Theatre Project. Prospectus. St. John's. 2010.

Nolan, Michael. "MUN Drama and Shakespeare." Brave New Worlds:

Shakespeare in Newfoundland and Labrador, edited by Robert Ormsby, Memorial University Libraries, 2018, pp. 89-91. Memorial U of Newfoundland Digital Archives Initiative, collections.mun.ca/cdm/ compoundobject/collection/qeiipublic/id/465/rec/1.

Open Letter to the Board of Directors of Resource Foundation for the Arts.

St. John's, NL. 29 Mar 1979. Coll. 240 (2.02.015). Archives and

Special Collections, Memorial University of Newfoundland, St. John's, NL. Accessed 21 Sept. 2018.

Ormsby, Robert, editor. Brave New Worlds: Shakespeare in Nerfoundland and

Labrador. Memorial University Libraries, 2018. Memorial U of

Newfoundland Digital Archives Initiative, collections.mun.ca/cdm/ compoundobject/collection/qeiipublic/id/465/rec/1. Accessed on 4 November 2019

- "Festival Shakespeare and Newfoundland as Tourist Place." Shakespeare and Tourism. Routledge. Forthcoming 2021.

- "Introduction: Shakespeare in Newfoundland and Labrador — 'Who's There?"' Brave New Worlds: Shakespeare in Nerwfoundland and Labrador. Edited by Robert Ormsby. Memorial University Libraries, 2018. Memorial U of Newfoundland Digital Archives Initiative, collections. mun.ca/cdm/compoundobject/collection/qeiipublic/id/465/rec/1.1-8.

Accessed on 4 November 2019

Overton, James. "Towards a Critical Analysis of Neo-Nationalism in Newfoundland." Underdevelopment and Social Movements in Atlantic Canada, edited by Robert J. Brym, R. James Sacouman, and Barbara Neis, New Hogtown P, 1979, pp. 219-49.

. "A Newfoundland Culture?" Journal of Canadian Studies, vol. 23, nos. $1 \& 2,1988$, pp. 5-22.

_. "Sparking a Cultural Revolution: Joey Smallwood, Farley Mowat, Harold Horwood, and Newfoundland's Cultural Renaissance."

Newfoundland and Labrador Studies, vol. 16, no. 2, 2000, pp. 166-204. Perchance Theatre. Perchance Theatre at Cupids: Sustainability Project. https:// www.perchancetheatre.com/sustainability-project-report.html.

Accessed 10 June 2020. 
Perlin, John. "Shakespeare at the Arts and Culture Centre." Brave New Worlds: Shakespeare in Newfoundland and Labrador, edited by Robert Ormsby, Memorial University Libraries, 2018, pp. 56-58. Memorial U of Newfoundland Digital Archives Initiative, collections.mun.ca/cdm/ compoundobject/collection/qeiipublic/id/465/rec/1. Accessed on 4 November 2019

Peters, Helen. "From Salt Cod to Salt Filets." Canadian Theatre Review, vol. 64, 1990, pp. 13-17.

—. "Introduction." The Plays of CODCO, edited by Helen Peters, Peter Lang, 1992, pp. xi-xxxi.

- editor. Stars in the Sky Morning: Collective Plays of Newfoundland and Labrador, Killick Press, 1996.

- "Introduction." Stars in the Sky Morning: Collective Plays of Newfoundland and Labrador, edited by Helen Peters, Killick Press, 1996, pp. xii-xlv. Pocius, Gerald. "The Mummers Song in Newfoundland: Intellectuals, Revivalists, and Cultural Nativism.” Nerwfoundland Studies, vol. 4, no. 1, 1988, pp. 57-85.

Porter, Helen. "Codco: A Unique Comic Theatre Troupe Reflects the Culture of Newfoundland." Performing Arts in Canada, vol. 22, 1985-86, pp. 36-38.

Public Meeting. 14 Aug. 1979. Coll. 126 (2.03.001). Archives and Special

Collections, Memorial University of Newfoundland, St. John's, NL. Accessed 21 May 2018.

Report of the Arbitration Committee. St. John's, NL. Coll. 126 (2.03.001).

Archives and Special Collections, Memorial University of Newfoundland, St. John's, NL. Accessed 21 Sept. 2018.

Resource Centre for the Arts (RCA). Attendance figures, Coll. 125

(4.01.001). Archives and Special Collections, Memorial University of Newfoundland, St. John's, NL. Accessed 11 May 2018.

- The Newfoundland Tempest. Sound Recording. St. John's ACC. 17 Feb. 1982. XZ1MSA, Box 13, L.W. Connolly Archives, University of Guelph Library, Guelph, ON. Accessed 7 June 2018.

—. Program for The Newfoundland Tempest. St. John's, 1982. Coll. 125 (7.09.036). Archives and Special Collections, Memorial University of Newfoundland, St. John's, NL. Accessed 11 May 2018. 
Publicity Checklist. Coll. 125 (7.09.036). Archives and Special

Collections, Memorial University of Newfoundland, St. John's, NL.

Accessed 11 May 2018.

- Public Service Announcement. Coll. 125 (7.09.036). Archives and

Special Collections, Memorial University, St. John's, NL. Accessed 11

May 2018.

Resource Foundation for the Arts (RFA). A Proposal To Elicit the Support of St. John's City Council with Operation of the L.S.P.U. Hall as a

Downtown Cultural Centre. 26 Oct. 1976. Coll. 126 (2.03.001).

Archives and Special Collections, Memorial University of Newfoundland, St. John's, NL. Accessed 21 May 2018.

- Quick-Reference Information on the LSPU Hall Downtown

Cultural Centre. 1978. Coll. 126 (2.03.001). Archives and Special

Collections, Memorial University of Newfoundland, St. John's, NL.

Accessed 21 May 2018.

Rimsay, Linda. "Reminding Us That Shakespeare Isn't Stuffy." The Daily

Nerws [St. John's], 11 Feb. 1982, p. 21.

Rix, Lucy. "Maintaining the State of Emergence/y: Aimé Césaire's Une

tempête." The Tempest and Its Travels, edited by Peter Hulme and

William H. Sherman, U of Pennsylvania P, 2000, pp. 236-49.

Rompkey, Ronald. "The Idea of Newfoundland and Arts Policy Since

Confederation.” Newfoundland Studies, vol. 14, no. 2, 1998, pp. 267-81.

Schweitzer, Marlis. "An 'Unmanly and Insidious Attack': Child Actress Jean

Davenport and the Performance of Masculinity in 1840s Jamaica and

Newfoundland." Theatre Research in Canada/Recherches théâtrales au

Canada, vol. 35, no. 1, 2014, pp. 49-68.

Shakespeare, William. The Tempest, edited by Stephen Orgel. Oxford UP, 1987.

Sheila’s Brush. Canada Council Grant Application. 1979. Coll. 240

(5.02.001). Archives and Special Collections, Memorial University of

Newfoundland, St. John's, NL. Accessed 25 May 2018.

. "A Short History on Sheila's Brush." Coll. 240 (5.02.001). Archives

and Special Collections, Memorial University of Newfoundland, St.

John's, NL. Accessed 25 May 2018.

Skidmore, Jamie. "Three Newfoundland Playwrights." Pathways of Creativity

in Contemporary Newfoundland and Labrador, edited by María Jesús

Hernáes Lerena, Cambridge Scholars Publishing, 2015, pp. 191-210. 
Skinner, Ches. "Newfoundland Amateur Drama-Historical Sources." Proceedings of the Workshop on Nerfoundland Theatre Research, edited by Denyse Lynde, Helen Peters, and Richard Buehler, Memorial University of Newfoundland, 1993, pp. 88-93.

"Sounds and Sweet Airs." Arts and Culture Centres. artsandculturecentre. com/Online/default.asp?doWork::WScontent::-loadArticle=Load\&BOparam::WScontent::loadArticle::article_id=73A704AF0D21-498E-8FE4-A620653E6723. Accessed 23 April 2020

Sugars, Cynthia. "Genetic Phantoms: Geography, History, and Ancestral Inheritance in Kenneth Harvey's The Town That Forgot How to Breathe and Michael Crummey's Galore." Newfoundand and Labrador Studies, vol. 25, no. 1, 2010, pp. 7-36.

Walsh, Des. "Working with the Best: Shakespeare in Newfoundland." Arts Information, Mar. 1984, pp. 10-11.

Warwick, Paddy. "Newfoundland Tempest.” The Evening Telegram [St. John's], 10 Feb. 1982.

Webb, Jeff. "Constructing Community and Consumers: Joseph R. Smallwood's Barrelman Radio Programme." Journal of the Canadian Historical Association, vol. 8, 1997, pp. 165-86.

- Observing the Outports: Describing Newfoundland Culture, 1950-1980. U of Toronto P, 2016.

. "Repertoire and Reception: Musical Culture in St. John's Newfoundland, 1930-1945." Journal of Canadian Studies, vol. 42, 2008, pp. 117-39.

. "The Rise and Fall of Memorial University's Extension Service, 1959-91." Newfoundland and Labrador Studies, vol. 29, no. 1, 2014, pp. 84-116.

_. "We can hardly go wrong': Staging Macbeth in the Little Theatre." Brave New Worlds: Shakespeare in Newfoundland and Labrador, edited by Robert Ormsby, Memorial University Libraries, 2018, pp. 80-84. Memorial U of Newfoundland Digital Archives Initiative, collections. mun.ca/cdm/compoundobject/collection/qeiipublic/id/465/rec/1.

Accessed on 4 November 2019

Yeo, Leslie. A Thousand and One First Nights. Mosaic Press, 1998. 